\title{
Advances in Cardiovascular Biomarker Discovery
}

\author{
Crystal M. Ghantous ${ }^{1}{ }^{\complement}$, Layla Kamareddine ${ }^{2,3}$, Rima Farhat ${ }^{4}$, Fouad A. Zouein ${ }^{5}{ }^{\oplus}$, \\ Stefania Mondello ${ }^{6,7}$ (1) , Firas Kobeissy ${ }^{8}\left(\right.$ i) and Asad Zeidan ${ }^{3,9, *}$
}

1 Department of Nursing and Health Sciences, Faculty of Nursing and Health Sciences, Notre Dame University-Louaize, Keserwan 72, Lebanon; cghantous@ndu.edu.lb

2 Biomedical Sciences Department, College of Health Sciences, QU Health, Qatar University, Doha 2713, Qatar; lkamareddine@qu.edu.qa

3 Biomedical and Pharmaceutical Research Unit, QU Health, Qatar University, Doha 2713, Qatar

4 Department of Anatomy, Cell Biology and Physiology, Faculty of Medicine, American University of Beirut, Beirut 1107, Lebanon; rf57@aub.edu.lb

5 Department of Pharmacology and Toxicology, Faculty of Medicine, American University of Beirut, Beirut 1107, Lebanon; fz15@aub.edu.lb

6 Oasi Research Institute-IRCCS, 94018 Troina, Italy; stm_mondello@hotmail.com

7 Department of Biomedical and Dental Sciences and Morpho-functional Imaging, University of Messina, 98125 Messina, Italy

8 Department of Biochemistry and Molecular Genetics, Faculty of Medicine, American University of Beirut, Beirut 1107, Lebanon; firasko@gmail.com

9 Department of Basic Medical Science, Faculty of Medicine, QU Health, Qatar University, Doha 2713, Qatar

* Correspondence: a.zeidan@qu.edu.qa; Tel.: +97-431-309-19

Received: 23 October 2020; Accepted: 20 November 2020; Published: 30 November 2020

check for updates

\begin{abstract}
Cardiovascular diseases are the leading causes of mortality worldwide. Among them, hypertension and its pathological complications pose a major risk for the development of other cardiovascular diseases, including heart failure and stroke. Identifying novel and early stage biomarkers of hypertension and other cardiovascular diseases is of paramount importance in predicting and preventing the major morbidity and mortality associated with these diseases. Biomarkers of such diseases or predisposition to their development are identified by changes in a specific indicator's expression between healthy individuals and patients. These include changes in protein and microRNA (miRNA) levels. Protein profiling using mass spectrometry and miRNA screening utilizing microarray and sequencing have facilitated the discovery of proteins and miRNA as biomarker candidates. In this review, we summarized some of the different, promising early stage protein and miRNA biomarker candidates as well as the currently used biomarkers for hypertension and other cardiovascular diseases. Although a number of promising markers have been identified, it is unlikely that a single biomarker will unambiguously aid in the classification of these diseases. A multi-marker panel-strategy appears useful and promising for classifying and refining risk stratification among patients with cardiovascular disease.
\end{abstract}

Keywords: biomarkers; cardiovascular diseases; hypertension; proteomics; miRNA

\section{Hypertension}

Cardiovascular disease (CVD) refers to a group of disorders that includes hypertension, coronary artery disease, peripheral artery disease, stroke, congenital heart disease, and heart failure [1]. It is the leading cause of death worldwide, accounting for approximately 17.9 million deaths in 2016 alone [2]. The annual cost for the management of CVDs in the US in 2015 was an estimated \$351.3 billion, accounting for the highest costing group in all diagnostic groups, and hypertension and its associated complications were responsible for more than $50 \%$ of deaths caused by CVDs [3]. 
Medications and health care services for hypertension cost the US approximately $\$ 51.2$ billion in 2014 [4]. Being a CVD itself, hypertension is also a major risk factor for the development of other cardiovascular diseases, such as stroke, renal disease, and heart failure [5,6]. Clinically, hypertensive patients are divided into two groups: (1) stage 1 hypertension, where systolic/diastolic blood pressure consistently ranges between 140/90 and 159/99 $\mathrm{mmHg}$ [7], and (2) stage 2 hypertension, where systolic/diastolic blood pressure consistently exceeds 160/100 mmHg [8]. Based on its etiology, hypertension can be classified as either essential (primary) or secondary. Essential hypertension is the most common form of hypertension. Its occurrence is generally idiopathic with undefined mechanisms [6], but highly correlates with family history, sedentary lifestyle, salt intake, obesity, age, smoking, and stress [6,9]. Secondary hypertension, on the other hand, is directly linked to pre-existing pathophysiological disorders, such as renal disease, endocrine disorders, neurological diseases, and pregnancy [6,10].

Accurately diagnosing hypertension is not as simple as other diseases. For instance, diseases like cancer are assertively identified by tools like magnetic resonance imaging (MRI), histological-pathological examination, and molecular workup. However, blood pressure measurements may not be stable and elevated at all times. It is crucial to discover and use early stage biomarkers that indicate the early development of hypertension as well as other cardiovascular diseases before these diseases and their associated complications have already occurred.

With chronic hypertension, the arteries undergo vascular remodeling. Their walls become stiffer and less elastic, thereby increasing the risk of vascular occlusion and rupture, and subsequently leading to organ damage or failure [11,12]. Among its manifestations, hypertension promotes vascular smooth muscle cell (VSMC) remodeling [12], endothelial cell dysfunction, and atherosclerosis [13].

\subsection{Hypertension and Vascular Smooth Muscle Cell Remodeling}

VSMCs reside in the tunica media, the middle layer of blood vessels and the thickest layer in arteries. They contract and relax in response to different stimuli in order to regulate blood flow to the tissues that the vessels irrigate. In essential hypertension, small resistance arteries undergo vascular remodeling and become characterized by an increased wall thickness to lumen ratio and a narrower lumen [14,15].

Several molecular mechanisms mediate hypertension-induced vascular remodeling. The force of mechanical stretch exerted by hypertension on the vascular wall promotes the production of reactive oxygen species (ROS) [16], which in turn induce VSMC remodeling [17,18]. The excessive force of stretch mediated by hypertension also causes alterations in the extracellular matrix, activating the RhoA pathway, which in turn promotes actin cytoskeleton remodeling in VSMCs [16]; the hypertension-induced activation of extracellular signal-regulated kinases 1 and 2 (ERK1/2) and protein kinase B (AKT) also results in vascular remodeling $[19,20]$. Moreover, caveolae, which are lipid raft invaginations in the plasma membrane, mediate hypertension-induced VSMC modeling via endothelial nitric oxide synthase (eNOS) and endothelin receptor type A (ETA) [21-23]. Studies have also shown that angiotensin II type 1 receptor $\left(\mathrm{AT}_{1}\right)$, platelet-derived growth factor receptor (PDGF-R), and specific ion channels, like voltage-gated calcium channels, are implicated in hypertension-induced VSMC remodeling [19,24-27] (Figure 1). 


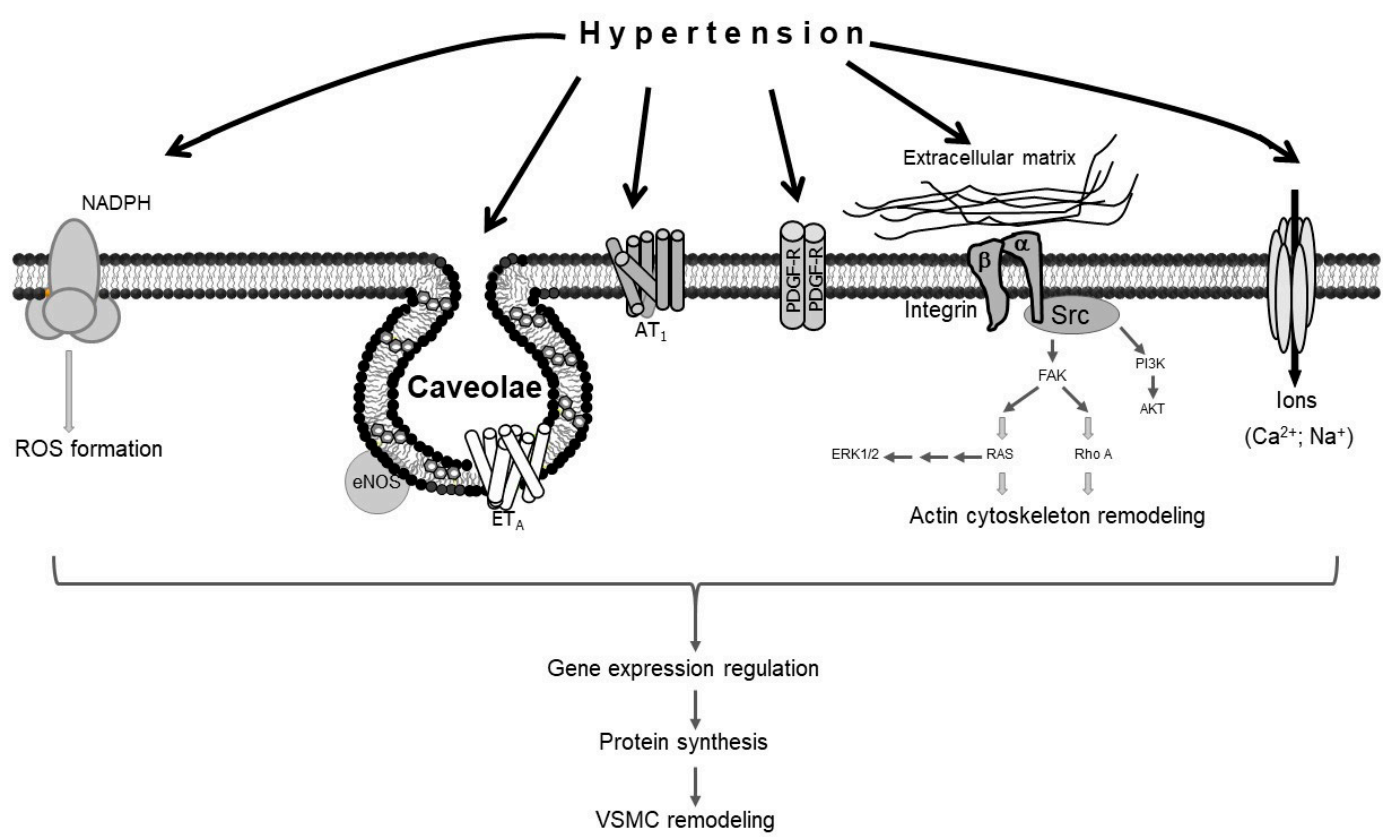

Figure 1. Schematic representation of vascular smooth muscle cell (VSMC) remodeling in response to hypertension. Hypertension stimulates different sensors in the plasma membrane of VSMCs, activating several signaling pathways that lead to VSMC remodeling.

\subsection{Hypertension and Endothelial Dysfunction}

Endothelial cells are located in the tunica intima layer of blood vessels and form the luminal surface. Blood pressure exerts two types of forces on the endothelial cells: outward mechanical stretch and shear stress. When blood pressure is low, endothelial cells secrete a number of vasoactive molecules, like angiotensin II, endothelin-1, ROS, and prostanoids, which act on VSMCs to promote VSMC contraction and subsequent vasoconstriction [28,29]. In contrast, when blood pressure rises, vasodilator substances like nitric oxide (NO), prostacyclin, and endothelium-derived hyperpolarizing factor are produced by endothelial cells $[30,31]$.

The forces exerted by hypertension cause endothelial damage and dysfunction, resulting in reduced production of NO [32,33]. Consequently, blood pressure-induced vasodilation is compromised. Moreover, hypertension-mediated endothelial dysfunction promotes the development of atherosclerosis.

Atherosclerosis is associated with the build-up of an atheromatous plaque, which is mainly composed of oxidized low-density lipoprotein (LDL) and macrophages inside the walls of arteries. It is a risk factor for coronary artery disease, myocardial infarction (MI), hypertension, stroke, and peripheral artery disease [34-37]. Arterial calcification is associated with atheroma progression and alters the mechanical properties of the vascular wall, thereby increasing the risk of rupture of the atherosclerotic plaque [38]. Discovering distinctive biomarkers that indicate early atherosclerosis development may allow the early detection of atherosclerosis, which in turn would encourage the patient to make healthy lifestyle changes or begin treatment in order to prevent its progression.

\section{Biomarkers}

The discovery of biomarkers has become an essential and vibrant field in biomedical and clinical research. Biomarkers are objectively measured and used to indicate a certain biological state, whether physiological, pathological, or pharmacological [39]. Moreover, they can provide information about normal molecular physiology as well as disease activity and progression. They are also used by pharmacologists to gain insight into the mechanistic action of drugs and their efficacy, safety, 
and off-target actions [40]. Some biomarkers could be risk factors themselves and therefore potential targets of therapy [41,42]. Biomarkers may be found in biofluids, such as the blood and urine, and tissues (biosample), as well as recorded using tests like the electrocardiogram [43]. In the following sections, we outline the roles of validated blood-based markers for CVDs and discuss and provide perspectives on the emerging candidates, which include proteins and microRNAs (miRNAs).

\subsection{Classical Biomarkers of Cardiovascular Disease}

Obesity, smoking, hypertension, gender, age, LDL cholesterol, diabetes, and sedentary lifestyle are well-known risk factors for CVD development. However, these factors can only be used to pinpoint patients at high risk but never prevent or predict an acute or fatal attack, such as MI. Some of these factors have been used in the Framingham Risk Score [44], an algorithm that calculates the 10-year risk of developing cardiovascular adverse events. Low risk individuals have a score of less than 10\%, while intermediate risk is shown at 10-20\%, and high risk is seen when the score is over $20 \%$ [ 44 ].

There are currently several clinical biomarkers that are associated with cardiovascular events. These biomarkers include: C-reactive protein (CRP), cardiac troponins I and T (cTnI and cTnT), B-type natriuretic peptides (BNP and NT-proBNP), and D-dimer [45-47] (Summarized in Table 1). CRP is a pattern recognition molecule that is elevated in inflammatory conditions, such as atherosclerosis. CRP levels predict cardiovascular morbidity [48], and elevated CRP levels are directly correlated with future cardiovascular risks [49]. The cardiac troponins cTnI and cTnT are particularly significant biomarkers in diagnosing acute MI and in stratifying risks in acute coronary syndrome [50,51]. The B-type natriuretic peptides (BNP and NT-proBNP) are used as biomarkers to diagnose heart failure in both acute and chronic states [52]. D-dimer is a biomarker of thrombosis, cardiovascular mortality, acute aortic dissection, and ischemic heart disease $[45,53,54]$. Although these biomarkers are routinely used in clinical practice and have helped doctors save lives, they detect cardiovascular events after an attack has already occurred (late stage biomarkers). The challenge is to find biomarkers that detect early stage CVD in order to significantly reduce morbidity and mortality associated with cardiovascular events and improve prognosis.

Table 1. Late stage protein biomarkers of cardiovascular disease.

\begin{tabular}{|c|c|c|c|c|}
\hline $\begin{array}{l}\text { Proteins Associated } \\
\text { with CVD }\end{array}$ & Function/Description & $\begin{array}{c}\text { Type of CVD They Help } \\
\text { Diagnose }\end{array}$ & $\begin{array}{l}\text { Levels in } \\
\text { CVD }\end{array}$ & Reference(s) \\
\hline C-reactive protein (CRP) & $\begin{array}{l}\text { Pattern recognition molecule that } \\
\text { is increased in inflammation or } \\
\text { tissue injury }\end{array}$ & $\begin{array}{l}\text { Inflammatory conditions } \\
\text { (atherosclerosis) }\end{array}$ & Elevated & {$[55,56]$} \\
\hline Cardiac troponin I (cTnI) & $\begin{array}{l}\text { The subunit of troponin that binds } \\
\text { to actin and maintains the } \\
\text { troponin-tropomyosin complex }\end{array}$ & $\begin{array}{l}\text { Acute myocardial infarction and } \\
\text { acute coronary syndrome }\end{array}$ & Elevated & [50] \\
\hline Cardiac troponin $\mathrm{T}(\mathrm{cTn} \mathrm{T})$ & $\begin{array}{l}\text { The subunit of troponin that binds } \\
\text { to tropomyosin to form a } \\
\text { troponin-tropomyosin complex }\end{array}$ & $\begin{array}{l}\text { Acute myocardial infarction and } \\
\text { acute coronary syndrome }\end{array}$ & Elevated & [50] \\
\hline $\begin{array}{l}\text { B-type natriuretic peptides } \\
\text { (BNP and NT-proBNP) }\end{array}$ & $\begin{array}{l}\text { Reduces plasma volume and } \\
\text { blood pressure }\end{array}$ & $\begin{array}{l}\text { Ventricular hypertrophy and } \\
\text { acute and chronic heart failure }\end{array}$ & Elevated & [52] \\
\hline D-dimer & $\begin{array}{l}\text { Fibrin degradation product from } \\
\text { fibrinolysis of blood clots }\end{array}$ & $\begin{array}{l}\text { Thrombosis, ischemic heart } \\
\text { disease, acute aortic dissection, } \\
\text { cardiovascular mortality }\end{array}$ & Elevated & {$[46,53]$} \\
\hline Tetranectin & $\begin{array}{l}\text { Binds to kringle } 4 \text { of circulating } \\
\text { plasminogen, upregulating the } \\
\text { activation of plasminogen into } \\
\text { plasmin in fibrinolysis }\end{array}$ & $\begin{array}{l}\text { Presence and severity of diseased } \\
\text { coronary arteries }\end{array}$ & Elevated & [57] \\
\hline $\begin{array}{l}\text { Serum cyclin-dependent } \\
\text { kinase } 9\end{array}$ & $\begin{array}{l}\text { Regulation of cell cycle and } \\
\text { activation of inflammatory } \\
\text { response genes }\end{array}$ & Atherosclerotic inflammation & Elevated & [58] \\
\hline
\end{tabular}


Table 1. Cont

\begin{tabular}{|c|c|c|c|c|}
\hline $\begin{array}{c}\text { Proteins Associated } \\
\text { with CVD }\end{array}$ & Function/Description & $\begin{array}{c}\text { Type of CVD They Help } \\
\text { Diagnose }\end{array}$ & $\begin{array}{l}\text { Levels in } \\
\text { CVD }\end{array}$ & Reference(s) \\
\hline Endogenous ouabain & $\begin{array}{l}\text { Glycoside that inhibits the } \\
\mathrm{Na}^{+} / \mathrm{K}^{+} \text {-ATPase }\end{array}$ & Heart Failure & Elevated & [59] \\
\hline Haptoglobin & $\begin{array}{l}\text { Acute phase protein that binds to } \\
\text { hemoglobin and also has } \\
\text { antioxidant activity }\end{array}$ & Atherothrombotic ischemic stroke & Elevated & {$[60]$} \\
\hline
\end{tabular}

\subsection{Early Stage Biomarkers of Cardiovascular Disease}

Discovering early stage biomarkers of CVD is crucial in predicting future cardiovascular events in both healthy and unhealthy individuals. Protein profiling using proteomic techniques and mRNA screening utilizing microarray platform and RNA sequencing allow the identification of dysregulated proteins and differentially expressed genes in early stages of disease. Table 2 lists some important early stage biomarkers of CVDs. With these biomarkers, biological mechanisms of CVDs can be better understood, and the prognoses of CVDs can be improved. For instance, Ceholski et al. have reported that lethal dilated cardiomyopathy and heart failure can be detected by a dominant Arg->Cys mutation at residue 9 in the phospholamban gene (PLN-R9C) [61]. Thus, PLN-R9C has the potential of serving as an early stage biomarker for cardiomyopathy and subsequent heart failure.

Another early detection biomarker is myeloperoxidase (MPO), an enzyme that catalyzes the formation of hyperchlorite from chloride and hydrogen peroxide (Table 2). It is secreted by active macrophages and neutrophils during an inflammatory process [62,63]. MPO and metalloproteases break down the collagen layer in an atherosclerotic plaque, thus leading to its erosion and rupture. High MPO levels are considered an early detection biomarker of CVD due to their correlation with atheroma instability. Clinical trials have found that elevated MPO levels are early indicators of coronary artery disease [64] even before detection by angiography or cardiac troponin levels [62]. However, $\mathrm{MPO}$ is not necessarily specific to CVD because macrophage and neutrophil activation can also occur in response to infections and inflammatory responses unrelated to the cardiovascular system [62].

Secreted frizzled related proteins (sFRPs) are secreted at the early stages of MI and function as Wnt antagonists [65] (Table 2). The Wnt pathway physiologically plays a role in cytoskeleton regulation and $\beta$-catenin stabilization, which in turn translocates to the nucleus to activate the gene expression that imposes an anti-apoptotic phenotype. When the Wnt pathway is antagonized by sFRP3, a pro-apoptotic pathway typical of MI and heart failure is activated [65]. Thus, MI, heart failure, and its adverse outcomes are associated with high circulating levels of sFRP3 [66], suggesting a potential role for sFRP3 as an early stage diagnostic biomarker of heart failure. Although there are more biomarkers that have been reported to be associated with CVD development (Table 2), the discovery of novel gene/protein biomarkers is still necessary to improve the prognostic accuracy of CVDs.

Table 2. Early stage protein biomarkers of cardiovascular disease.

\begin{tabular}{|c|c|c|c|c|}
\hline $\begin{array}{l}\text { Proteins Associated } \\
\text { with CVD }\end{array}$ & Function/Description & $\begin{array}{l}\text { Type of CVD They } \\
\text { Help Diagnose }\end{array}$ & $\begin{array}{c}\text { Changes/Levels } \\
\text { in CVD }\end{array}$ & Reference(s) \\
\hline Phospholamban & $\begin{array}{l}\text { Regulates cardiac contractility by } \\
\text { inhibiting sarco/endoplasmic reticulum } \\
\text { calcium transport ATPase (SERCA) in } \\
\text { its dephosphorylated form }\end{array}$ & $\begin{array}{l}\text { Early onset of dilated } \\
\text { cardiomyopathy and } \\
\text { heart failure }\end{array}$ & $\begin{array}{c}\text { Dominant Arg-> Cys } \\
\text { mutation at residue } 9 \\
\text { (loss-of-function } \\
\text { mutation) }\end{array}$ & [61] \\
\hline Myeloperoxidase (MPO) & $\begin{array}{l}\text { - Catalyzes the formation of } \\
\text { hyperchlorite from chloride and } \\
\text { hydrogen peroxide } \\
\text { - Bactericidal agent produced by } \\
\text { monocytes and activated neutrophils } \\
\text { - Promotes oxidation of LDL and } \\
\text { oxidative modification of } \\
\text { apolipoprotein A-I }\end{array}$ & $\begin{array}{l}\text { Unstable atheroma, coronary } \\
\text { artery disease, ischemic heart } \\
\text { disease, stroke }\end{array}$ & Elevated & [67-69] \\
\hline
\end{tabular}


Table 2. Cont.

\begin{tabular}{|c|c|c|c|c|}
\hline $\begin{array}{l}\text { Proteins Associated } \\
\text { with CVD }\end{array}$ & Function/Description & $\begin{array}{l}\text { Type of CVD They } \\
\text { Help Diagnose }\end{array}$ & $\begin{array}{l}\text { Changes/Levels } \\
\text { in CVD }\end{array}$ & Reference(s) \\
\hline $\begin{array}{l}\text { Secreted frizzled related } \\
\text { proteins (sFRPs) }\end{array}$ & Modulate Wnt signaling & $\begin{array}{l}\text { Myocardial infarction and } \\
\text { heart failure }\end{array}$ & Elevated & {$[65,66]$} \\
\hline Serum amyloid A & $\begin{array}{l}\text { Acute phase protein that increases the } \\
\text { expression of pro-thrombotic and } \\
\text { pro-inflammatory molecules }\end{array}$ & $\begin{array}{l}\text { Coronary artery disease, } \\
\text { atherosclerotic plaque } \\
\text { destabilization, acute } \\
\text { aortic dissection }\end{array}$ & Elevated & [70-73] \\
\hline ß 2-microglobulin & $\begin{array}{l}\text { Membrane protein that associates with } \\
\text { heavy chains of class I major } \\
\text { histocompatibility complex proteins }\end{array}$ & Peripheral arterial disease & Elevated & [74] \\
\hline $\begin{array}{l}\text { Junctional adhesion } \\
\text { molecule A (JAM-A) }\end{array}$ & $\begin{array}{l}\text { Regulates tight junction permeability } \\
\text { and integrity of endothelial and } \\
\text { epithelial cells }\end{array}$ & $\begin{array}{l}\text { Acute endothelial activation } \\
\text { and dysfunction }\end{array}$ & Elevated & [75] \\
\hline $\begin{array}{l}\text { Platelet/endothelial cell } \\
\text { adhesion molecule-1 } \\
\text { (PECAM-1) }\end{array}$ & $\begin{array}{l}\text { Transduces mechanical signals in } \\
\text { endothelial cells and regulates } \\
\text { migration of leukocytes through the } \\
\text { endothelium }\end{array}$ & Acute coronary syndromes & Elevated & [76] \\
\hline $\begin{array}{l}\text { Vitamin D-binding protein } \\
\text { (VTDB) }\end{array}$ & $\begin{array}{l}\text { Binds to vitamin } \mathrm{D} \text { and its plasma } \\
\text { metabolites and transports them to } \\
\text { target tissues }\end{array}$ & Coronary artery stenosis & Reduced & [77] \\
\hline
\end{tabular}

\subsection{Second-Generation Biomarkers of Cardiovascular Disease}

New research is directed at discovering second-generation biomarkers for CVD. Among them, miRNAs have been examined as potential biomarkers for several diseases, including cancer and neurodegenerative diseases [78,79]. However, their use in the cardiovascular field is relatively recent. A recent PubMed search for "miRNAs and human cardiovascular disease" resulted in 6780 hits versus "protein biomarkers and human cardiovascular disease", which resulted in 64,902 hits (PubMed search Keywords: biomarkers, cardiovascular disease, human, miRNAs (or microRNAs), protein; November 2020). Thus, miRNAs are emerging as biomarkers in the areas of CVD with promising potential [80,81].

MiRNAs are short, non-coding oligonucleotides (20-26 nucleotides) that function to silence mRNAs and thus inhibit the translation of mRNAs to proteins [82,83]. They move from one cell to another in a process of intercellular communication to silence specific mRNAs in the target cell. MiRNAs circulate in the body in membrane-derived vesicles, such as microvesicles, exosomes, and apoptotic bodies, as well as bound to RNA-binding proteins, like Argonaute 2 protein (AGO2), or by high-density lipoprotein (HDL) [82,84-87]. The role of miRNAs has been recently proposed as next-generation biomarkers due to their integral role in mediating cellular and molecular functions.

Circulating miRNAs have emerged as biomarkers for several reasons. First, they are stable and resistant to changes in $\mathrm{pH}$, temperature, freeze-thaw cycles, and long-term storage. Second, their sequences are generally conserved in different species. Third, several methods can be used to measure their levels, which have become correlated with different states of normal biological function as well as disease [88-90].

MiRNAs can be considered as reliable biomarkers for CVD. Table 3 summarizes some of the studied circulating miRNA biomarkers associated with CVD. For instance, miR-208 has been examined in the case of myocardial injury [91,92]. MiRNA array revealed that miR-208 is produced exclusively by the myocardium, and studies using real-time PCR confirmed that miR-208 levels in the plasma were significantly associated with myocardial injury similarly to cTnI [91], an already established biomarker of myocardial injury. Moreover, in patients with MI, the plasma levels of miR-208b and miR-499 were significantly elevated compared to the control and healthy individuals, and both were directly associated with cTnT and creatine phosphokinase [88]. Thus, miR-208b and miR-499 are potential candidate biomarkers for acute MI (Table 3). Interestingly, studies have shown that potential clinical confounders such as age, gender, renal function, and body mass index appear to not affect circulating miRNA levels [88], another aspect that makes miRNAs very appealing markers. 
In addition, dysregulation of miR-21, let-7, miR-221, miR-27b, miR-222, miR-126, and miR-130a has been implicated in atherosclerosis, angiogenesis, and coronary artery disease [93-96] (Table 3). MiRNAs are also being studied in children to detect potential future events of CVD. Dysregulation of miRNA expression has been reported in congenital heart defects, coronary artery disease, and cardiometabolic disorders [97-101] (Table 3).

Table 3. Non-protein biomarkers of cardiovascular disease.

\begin{tabular}{|c|c|c|c|}
\hline $\begin{array}{c}\text { Non-Proteins Associated } \\
\text { with CVD }\end{array}$ & $\begin{array}{l}\text { Type of CVD They } \\
\text { Help Diagnose }\end{array}$ & Changes/Levels in CVD & Reference(s) \\
\hline miR-208b and miR-499 & Acute myocardial infarction & Elevated & {$[88,91]$} \\
\hline $\begin{array}{l}\text { miR-21, miR-130a, miR-27b, } \\
\text { and miR-210 }\end{array}$ & $\begin{array}{c}\text { Atherosclerosis obliterans } \\
\text { and peripheral arterial } \\
\text { disease }\end{array}$ & Elevated & [102] \\
\hline miR-221 and miR-222 & $\begin{array}{l}\text { Atherosclerosis obliterans } \\
\text { and peripheral arterial } \\
\text { disease }\end{array}$ & Decreased & [102] \\
\hline $\begin{array}{l}\mathrm{miR}-34 \mathrm{a}, \mathrm{miR}-21 \text { and } \\
\text { miR-23a }\end{array}$ & Coronary artery disease & Elevated & [103] \\
\hline miR-26a & Hypertension & Decreased & [104] \\
\hline miR-29a & Obstructive cardiomyopathy & Elevated & [105] \\
\hline $\operatorname{miR}-29 \mathrm{c}$ & Aortic stenosis & Elevated & [105] \\
\hline miR-499 and miR-133a & Myocardial infarction & Elevated & [106] \\
\hline $\begin{array}{l}\text { miR-1, miR-208a, and } \\
\text { miR-499 }\end{array}$ & $\begin{array}{l}\text { Myocardial ischemic } \\
\text { reperfusion injury }\end{array}$ & Elevated & [107] \\
\hline miR-223 & Acute ischemic stroke & Elevated & [108] \\
\hline
\end{tabular}

\section{3. "Omics" and Systems Biology}

Current research is directed at discovering new ideal biomarkers for CVDs. One of the fastest and most efficient approaches employs the recently thriving "omics" techniques. The "omics" universe uses novel technologies to make measurements in the fields of genomics, transcriptomics, proteomics, and metabolomics. They detect DNA, RNA, proteins, lipids, and metabolites that are expressed in different organ systems, such as the cardiovascular system, by using plasma, urine, whole blood, and tissues. The omics approach provides extensive amounts of data at all levels of biological function, from the sequence and expression of genes to the expression patterns of proteins and metabolites [109]. These technologies allow the identification of various molecules that are involved in normal physiological function as well as pathological events and their use as biomarkers [110].

\subsection{Omics}

Omics studies allow samples to be analyzed as a global set of macromolecules. The acquired data do not focus on one specific target, but rather on a whole set of molecular species. This is the main aspect of systems biology, which connects molecules and their interactions to the function as a whole in the living system [111]. When the interconnections between pathways are deciphered, a universal physiological system can be deduced. As a result, predictions can be made about biological responses to certain abnormalities, such as environmental interventions and disease, thus providing information on the development, prevention, prediction, and treatment.

Omics techniques can generate up to thousands of results at once. This remarkable feature is attributed to their ability to detect even thousands of molecules and expression patterns in every experimental run and in a short time frame. As such, potential biomarkers of CVD can be easily 
identified. However, validation of these biomarkers using different methods is essential and necessary before translating these biomarkers from the lab into the clinic.

Proteomics profiles the expression and function of the protein complement on a global scale [112], providing a rapid and precise way to discover and identify proteins that are differentially expressed and to characterize certain disease states. Studying the proteome of injured, abnormal cardiovascular tissue allows researchers to identify biomarkers of disease development, progression, and treatment. Cardiomyopathy [113], myocardial ischemia [114], cardiac hypertrophy [115], and heart failure [116] have been analyzed using proteomic-based studies. However, the use of proteomics to discover biomarkers in CVD is still developing, but promising to be a very useful tool.

\subsection{Proteomic Advances in Detecting Vascular Diseases}

Atherosclerosis is usually silent until it evolves into a detrimental stage leading to stroke, MI, or peripheral artery disease, thus necessitating an early predictor marker that can detect these indications prior to being fully apparent. Previously, the standard method of studying atherosclerosis was to focus on a certain protein believed to play a role in the development or progression of atheromas. This approach, although targeted, is time-consuming and only focuses on one protein at a time. On the other hand, proteomic platforms allow a multitude of proteins potentially involved in atherosclerosis development to be identified and analyzed at once.

Comparing the differential expression of proteins in atherosclerotic plaques and affected arteries with non-affected arteries allows the detection of biomarkers involved in atherosclerosis, and as such are analyzed in biological fluids like plasma or urine. For example, haptoglobin and serum amyloid-A overexpression have been associated with atherothrombotic ischemic stroke, as studied by matrix-assisted laser desorption/ionization-time-of-flight (MALDI-TOF) mass spectrometry (MS) [60]. These findings were validated using enzyme-linked immunosorbent assay (ELISA) techniques [60]. Thus, levels of haptoglobin and serum amyloid A can be considered as biomarkers to predict atherothrombotic ischemic stroke as opposed to cardioembolic stroke (Table 1).

Another protein identified by proteomic studies is $\beta$ 2-microglobulin (Table 2). Surface-enhanced laser desorption/ionization-TOF (SELDI-TOF)-MS revealed that $\beta$ 2-microglobulin protein was significantly higher in the plasma of patients suffering from peripheral arterial disease with high prognostic values [74], as validated and confirmed by ELISA [74].

Several other proteins associated with unstable human carotid plaques have also been detected and classified as potential biomarkers. Topoisomerase-II- $\alpha$, caspase- 9 , junctional adhesion molecule-1 (JAM-1), Grb2-like adaptor protein (GADS), and TNF receptor-associated factor 4 (TRAF4) were found to be over-expressed in VSMCs, endothelial cells, and infiltrated macrophages [117]. G-protein-coupled receptor kinase-interacting protein (GIT1), c-src, and c-jun N-terminal kinase (JNK) were also upregulated in atherosclerotic plaques [117]. The discovery of early stage biomarkers in detecting and profiling CVD could be used as a prophylactic measure to prevent and reverse disease progression.

\section{Biomarkers Reflecting Hypertension Pathogenesis}

Since hypertension promotes the development of other CVDs, identifying antecedent, screening, and early stage diagnostic biomarkers is crucial in preventing hypertension-associated CVDs. Biomarkers of hypertension include those that indicate oxidative stress and inflammation since hypertension is associated with these states. Interestingly, adipokines have also emerged as potential biomarkers of hypertension. The following section describes these biomarkers in detail.

\subsection{Biomarkers Reflecting Oxidative Stress}

Hypertension is highly associated with oxidative stress, which in turn mediates hypertension-induced cardiovascular complications $[16,118]$. Several molecules have been shown to reflect the oxidative state. For instance, measurements of nitrite $\left(\mathrm{NO}_{2}{ }^{-}\right)$and nitrate $\left(\mathrm{NO}_{3}{ }^{-}\right)$can be used because they are markers of 
NO bioavailability. $\mathrm{NO}_{2}{ }^{-}$and $\mathrm{NO}_{3}{ }^{-}$are products of oxidative degradation of $\mathrm{NO}$, which physiologically causes vasodilation and prevents hypertension $[119,120]$ (Table 4). Their increased levels indicate a reduction in NO bioavailability and are thus associated with hypertension.

Asymmetric dimethylarginine (ADMA) and uric acid are other biomarkers for hypertension (Table 4). They inhibit the production of NO [121,122], so their increased levels are associated with reduced NO bioavailability and impaired vasodilation [123-125]. Moreover, ADMA levels are correlated with acute coronary events and can also be used as a biomarker for adverse cardiac outcomes [126]. ROS are another indicator of hypertension, since hypertension has been shown to directly increase ROS [16,118] (Summarized in Table 4). Although the aforementioned factors are widely used for the diagnosis of hypertension, there is an increasing demand to introduce more biological markers such as proteins and genes to improve the prediction of this condition. According to the Rat Genome Database, hundreds of genes are associated with hypertension (Rat: https://rgd.mcw.edu/rgdweb/elasticResults.html?term= hypertension\&chr=ALL\&start=\&stop=\&species=Rat\&category=Gene\&objectSearch=true; human: https://rgd.mcw.edu/rgdweb/elasticResults.html?term=hypertension\&chr=ALL\&start=\&stop= \&species $=$ Human\&category $=$ Gene\&objectSearch $=$ true).

Table 4. Molecules used as biomarkers of hypertension.

\begin{tabular}{cccc}
\hline Molecule & Function/Description & Levels in Hypertension & Reference(s) \\
\hline Nitrate and nitrite & $\begin{array}{c}\text { Physiological reservoir of NO } \\
\text { that can be reduced to NO to } \\
\text { regulate signal transduction }\end{array}$ & Elevated & Elevated \\
\hline $\begin{array}{c}\text { Asymmetric } \\
\text { dimethylarginine } \\
\text { (ADMA) }\end{array}$ & Inhibits nitric oxide synthase & [123] \\
\hline $\begin{array}{c}\text { Reactive oxygen species } \\
\text { (ROS) }\end{array}$ & $\begin{array}{c}\text { Highly reactive signal } \\
\text { transduction molecules that } \\
\text { cause nucleic acid, lipid, and } \\
\text { protein damage when present } \\
\text { in high concentrations } \\
\text { (oxidative stress) }\end{array}$ & Elevated & {$[118,128]$} \\
\hline Uric acid & $\begin{array}{c}\text { Final oxidation product of } \\
\text { purine metabolism }\end{array}$ & Elevated & {$[125,129]$} \\
\hline
\end{tabular}

\subsection{Protein Biomarkers Reflecting Inflammation}

Since hypertension is associated with vascular inflammation [130], markers of inflammation can be used as biomarkers for hypertension. The cell adhesion molecules vascular cell adhesion molecule (VCAM), intercellular adhesion molecule (ICAM), and platelet endothelial cell adhesion molecule (PECAM) allow inflammatory cells to adhere to the vascular wall [131-133]. High plasma levels of these molecules have been shown to be associated with hypertension [132-134].

Hypertensive patients have higher circulating levels of the inflammatory cytokines IL-1 $\beta$, IL-10, and tumor necrosis factor-alpha (TNF- $\alpha$ ), indicating the potential use of these inflammatory biomarkers as markers for hypertension [135]. Elevated levels of IL-1 $\beta$, IL-10, and TNF- $\alpha$ are also correlated with increased arterial stiffness associated with hypertension [135]. Moreover, IL- 6 and TNF- $\alpha$ levels can be used as independent risk factors for hypertension in healthy individuals [136] (Summarized in Table 5). 
Table 5. Inflammatory biomarkers of hypertension.

\begin{tabular}{|c|c|c|c|}
\hline Inflammatory Mediators & Function/Description & Levels in Hypertension & Reference(s) \\
\hline $\begin{array}{l}\text { Vascular cell adhesion } \\
\text { molecule (VCAM) }\end{array}$ & $\begin{array}{l}\text { Endothelial cell surface glycoprotein } \\
\text { that allows endothelial cell-leukocyte } \\
\text { adhesion in inflammation }\end{array}$ & Elevated & [137] \\
\hline $\begin{array}{l}\text { Intercellular adhesion } \\
\text { molecule (ICAM) }\end{array}$ & $\begin{array}{l}\text { Endothelial cell surface glycoprotein } \\
\text { that aids in endothelial cell-leukocyte } \\
\text { adhesion }\end{array}$ & Elevated & [138] \\
\hline $\begin{array}{l}\text { Platelet endothelial cell } \\
\text { adhesion molecule (PECAM) }\end{array}$ & $\begin{array}{l}\text { Cell surface protein of platelets, } \\
\text { monocytes, neutrophils, subsets of } \mathrm{T} \\
\text { cells that aids in leukocyte } \\
\text { transendothelial migration, and a } \\
\text { constituent of the endothelial } \\
\text { intercellular junctions }\end{array}$ & Elevated & [132] \\
\hline 6-keto-prostaglandin F1a & $\begin{array}{l}\text { Stable and active metabolite of } \\
\text { prostacyclin that promotes vasodilation } \\
\text { and inhibits platelet aggregation }\end{array}$ & Reduced & [139] \\
\hline C-reactive protein (CRP) & $\begin{array}{l}\text { Activates complement and binds to } \\
\text { foreign and damaged cells and tissue }\end{array}$ & Elevated & [140] \\
\hline $\begin{array}{l}\text { Tumor necrosis factor } \\
(\text { TNF- } \alpha)\end{array}$ & $\begin{array}{l}\text { Pro-inflammatory cytokine involved in } \\
\text { apoptosis, cell proliferation, } \\
\text { differentiation, and platelet activation }\end{array}$ & Elevated & {$[136,141]$} \\
\hline IL-10, IL-1 $\beta$ & $\begin{array}{l}\text { IL-10: Cytokine involved in mediating } \\
\text { the inflammatory response, B cell } \\
\text { survival, proliferation and antibody } \\
\text { production, and nuclear factor } \\
\text { kappa-light-chain-enhancer of activated } \\
\text { B cells (NF- } \mathrm{B} \text { ) activity } \\
\text { IL-1 } \beta \text { : Cytokine involved in regulating } \\
\text { the inflammatory response, cell } \\
\text { proliferation, differentiation, apoptosis, } \\
\text { and cyclooxygenase- } 2 \text { induction }\end{array}$ & Elevated & [135] \\
\hline IL-6 & Immune response in inflammation & Elevated & [136] \\
\hline P-selectin & $\begin{array}{l}\text { Cell adhesion molecule of platelets and } \\
\text { endothelial cells that works in the } \\
\text { interaction of leukocytes with platelets } \\
\text { or endothelial cells }\end{array}$ & Elevated & [142] \\
\hline Oxidized-LDL & $\begin{array}{l}\text { Taken up by macrophages to form foam } \\
\text { cells, a key step in atherosclerosis } \\
\text { development }\end{array}$ & Elevated & [139] \\
\hline Renin and prorenin & $\begin{array}{l}\text { Renin hydrolyzes angiotensinogen to } \\
\text { angiotensin I, while prorenin is its } \\
\text { inactive precursor }\end{array}$ & Elevated & [143] \\
\hline Leptin & $\begin{array}{l}\text { - Hormone mainly produced by } \\
\text { adipocytes that acts as a satiety factor to } \\
\text { increase energy expenditure by } \\
\text { signaling at the hypothalamus } \\
\text { - Promotes VSMC hypertrophy } \\
\text { - Pro-inflammatory cytokine } \\
\text { - Regulates puberty, menstrual cycles, } \\
\text { and reproductive function }\end{array}$ & Elevated & {$[144,145]$} \\
\hline Adiponectin & $\begin{array}{l}\text { - Insulin-sensitization and fatty acid } \\
\text { oxidation } \\
\text { - Anti-inflammatory - Cardioprotective }\end{array}$ & Reduced & [146] \\
\hline
\end{tabular}

\subsection{Adipokines as Biomarkers of Hypertension}

We and others have shown the significant association between the hormone leptin and hypertension $[16,144,145,147-149]$. Leptin is an obesity-associated adipokine that physiologically reduces appetite and increases energy expenditure. Research has shown that hypertensive patients 
have higher circulating leptin levels [150] and that leptin can be used as a predictor of new-onset hypertension [144]. Moreover, a recent biomedical and proteomics study conducted in our lab has shown that leptin is produced by VSMCs and that its synthesis is upregulated by hypertension (unpublished data and [16]). In turn, leptin contributes to VSMC hypertrophy and promotes atherosclerosis $[16,151]$ (Summarized in Table 5).

Adiponectin is another adipokine that is emerging as a biomarker for hypertension [152] (Table 5). This anti-inflammatory protein has been shown to exert cardioprotective effects on the heart by inhibiting pressure overload-induced cardiac hypertrophy and protecting against myocardial injury after ischemia-reperfusion [153-155]. Studies have shown that circulating adiponectin levels are reduced in hypertensive patients [146], which may explain the detrimental effects of hypertension on the cardiovascular system. In addition, we have recently shown that adiponectin is not only expressed by adipocytes, but also VSMCs, and that adiponectin supplementation reduces hypertension-induced VSMC hypertrophy $[17,156]$.

\section{Conclusions}

CVDs pose a huge global health and economic burden. They are the leading cause of death worldwide, and hypertension and its complications are responsible for an extremely high mortality rate associated with CVDs. Using biomarkers, namely early stage biomarkers of CVD, could potentially save many lives and help us win the fight against CVDs, all in the field of preventative medicine. The ideal biomarkers of CVD and hypertension or susceptibility to their development can be defined by alterations in a specific indicator's level/concentration between healthy individuals and patients. These include changes at the level of proteins, genes, and miRNAs. The identification of these molecules is facilitated with the use of proteomic approaches, such as MALDI-TOF and SELDI-TOF, allowing global profiling of the protein complement. The use of microarrays and miRNA sequencing for miRNA expression profiling have also given rise to the discovery of many miRNAs that could be used as biomarkers for CVD. In this review, we summarized different protein and miRNA biomarker candidates for hypertension as well as other CVDs.

It is very important that a biomarker be specific and sensitive to a certain disease. In the case of CVDs, many of the biomarkers used clinically are late stage biomarkers, indicating the presence of a disease that has already developed. Identifying early stage biomarkers of CVDs is of utmost importance in preventing these diseases from progressing and inducing their associated complications.

Proteomics is a promising tool for the discovery of new biomarkers. The use of new technology allows scientists to discover and validate new biomarkers related to the early progression of hypertension as well as other CVDs $[110,115]$. These new proteomic tools provide many advantages; first, they require a small volume of sample, and second, they can detect the effect of hypertension on several proteins simultaneously between samples. On the other hand, these methods require the presence of appropriate and specific antibodies for targeted biomarkers. MiRNAs have also emerged as potential diagnostic biomarkers for CVD. Unfortunately, measuring and comparing miRNA concentrations in body fluid samples is difficult due to the low levels of miRNAs. This will be a critical challenge in the near future.

Although a number of promising markers have been identified (Tables 1-5), it is unlikely that a single protein biomarker will unambiguously aid in the classification of normotensive and hypertensive patients as well as those suffering from other CVDs. A multi-marker panel-strategy appears as a useful and promising approach for classifying and refining risk stratification among patients with CVDs. Moreover, many biomarkers have already been identified and are medically used, but their use in the clinic has been limited to post-injury or post-attack. The challenge is not only limited to finding the best panel of biomarkers, but implementing their use in the clinic in a timely and cost-effective manner.

Author Contributions: C.M.G., S.M., L.K., and A.Z. contributed to writing the review. C.M.G., R.F., and A.Z. created the figure and tables. L.K., F.K., F.A.Z., and A.Z. reviewed and edited the manuscript. All authors have read and agreed to the published version of the manuscript. 
Funding: This research was funded by Qatar University [Grant QUERG-CMED-2020-3].

Acknowledgments: The authors thank the Faculty of Medicine at Qatar University for the grant given to Asad Zeidan to support this work.

Conflicts of Interest: The authors declare no conflict of interest.

\section{References}

1. Medicine, I.O. Cardiovascular disease. In A Nationwide Framework for Surveillance of Cardiovascular and Chronic Lung Diseases; National Academies Press (US): Washington, DC, USA, 2011.

2. World Health Organization. Cardiovascular Diseases (cvds) Fact Sheet. Available online: http://www.who. int/mediacentre/factsheets/fs317/en/ (accessed on 17 October 2020).

3. Virani, S.S.; Alonso, A.; Benjamin, E.J.; Bittencourt, M.S.; Callaway, C.W.; Carson, A.P.; Chamberlain, A.M.; Chang, A.R.; Cheng, S.; Delling, F.N.; et al. Heart disease and stroke statistics-2020 update: A report from the american heart association. Circulation 2020, 141, e139-e596. [CrossRef]

4. Wang, G.; Grosse, S.D.; Schooley, M.W. Conducting research on the economics of hypertension to improve cardiovascular health. Am. J. Prev. Med. 2017, 53, S115-S117. [CrossRef] [PubMed]

5. Levenson, J.W.; Skerrett, P.J.; Gaziano, J.M. Reducing the global burden of cardiovascular disease: The role of risk factors. Prev. Cardiol. 2002, 5, 188-199. [CrossRef]

6. Carretero, O.A.; Oparil, S. Essential hypertension. Part I: Definition and etiology. Circulation 2000, 101, 329-335. [CrossRef]

7. Sheppard, J.P.; Fletcher, K.; McManus, R.J.; Mant, J. Prevalence and costs of treating uncomplicated stage 1 hypertension in primary care: A cross-sectional analysis. Br. J. Gen. Pract. J. R. Coll. Gen. Pract. 2014, 64, e641-e648. [CrossRef]

8. Giles, T.D.; Materson, B.J. Treating stage 2 hypertension. J. Clin. Hypertens. 2005, 7, 464-470. [CrossRef]

9. Marteau, J.B.; Zaiou, M.; Siest, G.; Visvikis-Siest, S. Genetic determinants of blood pressure regulation. J. Hypertens. 2005, 23, 2127-2143. [CrossRef]

10. Chiong, J.R.; Aronow, W.S.; Khan, I.A.; Nair, C.K.; Vijayaraghavan, K.; Dart, R.A.; Behrenbeck, T.R.; Geraci, S.A. Secondary hypertension: Current diagnosis and treatment. Int. J. Cardiol. 2008, 124, 6-21. [CrossRef]

11. Lifton, R.P.; Gharavi, A.G.; Geller, D.S. Molecular mechanisms of human hypertension. Cell 2001, 104, 545-556. [CrossRef]

12. Shyu, K.G. Cellular and molecular effects of mechanical stretch on vascular cells and cardiac myocytes. Clin. Sci. 2009, 116, 377-389. [CrossRef]

13. Dharmashankar, K.; Widlansky, M.E. Vascular endothelial function and hypertension: Insights and directions. Curr. Hypertens. Rep. 2010, 12, 448-455. [CrossRef]

14. Aalkjaer, C.; Heagerty, A.M.; Petersen, K.K.; Swales, J.D.; Mulvany, M.J. Evidence for increased media thickness, increased neuronal amine uptake, and depressed excitation-Contraction coupling in isolated resistance vessels from essential hypertensives. Circ. Res. 1987, 61, 181-186. [CrossRef]

15. Arribas, S.M.; Hillier, C.; Gonzalez, C.; McGrory, S.; Dominiczak, A.F.; McGrath, J.C. Cellular aspects of vascular remodeling in hypertension revealed by confocal microscopy. Hypertension 1997, 30, 1455-1464. [CrossRef]

16. Ghantous, C.M.; Kobeissy, F.H.; Soudani, N.; Rahman, F.A.; Al-Hariri, M.; Itani, H.A.; Sabra, R.; Zeidan, A. Mechanical stretch-induced vascular hypertrophy occurs through modulation of leptin synthesis-mediated ros formation and gata-4 nuclear translocation. Front. Pharm. 2015, 6, 240. [CrossRef]

17. Nour-Eldine, W.; Ghantous, C.M.; Zibara, K.; Dib, L.; Issaa, H.; Itani, H.A.; El-Zein, N.; Zeidan, A. Adiponectin attenuates angiotensin ii-induced vascular smooth muscle cell remodeling through nitric oxide and the rhoa/rock pathway. Front. Pharm. 2016, 7, 86. [CrossRef]

18. Zhou, Y.; Zhang, M.J.; Li, B.H.; Chen, L.; Pi, Y.; Yin, Y.W.; Long, C.Y.; Wang, X.; Sun, M.J.; Chen, X.; et al. Ppargamma inhibits vsmc proliferation and migration via attenuating oxidative stress through upregulating ucp2. PLoS ONE 2016, 11, e0154720.

19. Yoshizumi, M.; Kyotani, Y.; Zhao, J.; Nakahira, K. Targeting the mitogen-activated protein kinase-mediated vascular smooth muscle cell remodeling by angiotensin ii. Ann. Transl. Med. 2020, 8, 157. [CrossRef] 
20. Liu, P.; Gu, Y.; Luo, J.; Ye, P.; Zheng, Y.; Yu, W.; Chen, S. Inhibition of src activation reverses pulmonary vascular remodeling in experimental pulmonary arterial hypertension via akt/mtor/hif-1<alpha $>$ signaling pathway. Exp. Cell Res. 2019, 380, 36-46. [CrossRef]

21. Forrester, S.J.; Elliott, K.J.; Kawai, T.; Obama, T.; Boyer, M.J.; Preston, K.J.; Yan, Z.; Eguchi, S.; Rizzo, V. Caveolin-1 deletion prevents hypertensive vascular remodeling induced by angiotensin ii. Hypertension 2017, 69, 79-86. [CrossRef]

22. Lian, X.; Matthaeus, C.; Kassmann, M.; Daumke, O.; Gollasch, M. Pathophysiological role of caveolae in hypertension. Front. Med. 2019, 6, 153. [CrossRef]

23. Titus, A.; Marappa-Ganeshan, R. Physiology, Endothelin; Statpearls: Treasure Island, FL, USA, 2020.

24. Hinoki, A.; Kimura, K.; Higuchi, S.; Eguchi, K.; Takaguri, A.; Ishimaru, K.; Frank, G.D.; Gerthoffer, W.T.; Sommerville, L.J.; Autieri, M.V.; et al. P21-activated kinase 1 participates in vascular remodeling in vitro and in vivo. Hypertension 2010, 55, 161-165. [CrossRef] [PubMed]

25. Jaminon, A.; Reesink, K.; Kroon, A.; Schurgers, L. The role of vascular smooth muscle cells in arterial remodeling: Focus on calcification-related processes. Int. J. Mol. Sci. 2019, 20, 5694. [CrossRef] [PubMed]

26. Brown, I.A.M.; Diederich, L.; Good, M.E.; DeLalio, L.J.; Murphy, S.A.; Cortese-Krott, M.M.; Hall, J.L.; Le, T.H.; Isakson, B.E. Vascular smooth muscle remodeling in conductive and resistance arteries in hypertension. Arter. Thromb. Vasc. Biol. 2018, 38, 1969-1985. [CrossRef] [PubMed]

27. Cheng, J.; Wen, J.; Wang, N.; Wang, C.; Xu, Q.; Yang, Y. Ion channels and vascular diseases. Arter. Thromb. Vasc. Biol. 2019, 39, e146-e156. [CrossRef] [PubMed]

28. Vanhoutte, P.M.; Tang, E.H. Endothelium-dependent contractions: When a good guy turns bad! J. Physiol. 2008, 586, 5295-5304. [CrossRef]

29. Versari, D.; Daghini, E.; Virdis, A.; Ghiadoni, L.; Taddei, S. Endothelium-dependent contractions and endothelial dysfunction in human hypertension. Br. J. Pharmacol. 2009, 157, 527-536. [CrossRef]

30. Feletou, M.; Vanhoutte, P.M. Endothelial dysfunction: A multifaceted disorder (the wiggers award lecture). Am. J. Physiol. Heart Circ. Physiol. 2006, 291, H985-H1002. [CrossRef]

31. Jia, G.; Durante, W.; Sowers, J.R. Endothelium-derived hyperpolarizing factors: A potential therapeutic target for vascular dysfunction in obesity and insulin resistance. Diabetes 2016, 65, 2118-2120. [CrossRef]

32. Sitia, S.; Tomasoni, L.; Atzeni, F.; Ambrosio, G.; Cordiano, C.; Catapano, A.; Tramontana, S.; Perticone, F.; Naccarato, P.; Camici, P.; et al. From endothelial dysfunction to atherosclerosis. Autoimmun. Rev. 2010, 9, 830-834. [CrossRef]

33. Taddei, S.; Ghiadoni, L.; Virdis, A.; Buralli, S.; Salvetti, A. Vasodilation to bradykinin is mediated by an ouabain-sensitive pathway as a compensatory mechanism for impaired nitric oxide availability in essential hypertensive patients. Circulation 1999, 100, 1400-1405. [CrossRef]

34. Garcia de Tena, J. Inflammation, atherosclerosis, and coronary artery disease. N. Engl. J. Med. 2005, 353, 429-430; author reply 429-430. [PubMed]

35. Li, J.J.; Chen, J.L. Inflammation may be a bridge connecting hypertension and atherosclerosis. Med. Hypotheses 2005, 64, 925-929. [CrossRef] [PubMed]

36. Elkind, M.S. Inflammation, atherosclerosis, and stroke. Neurologist 2006, 12, 140-148. [CrossRef]

37. Olin, J.W.; Sealove, B.A. Peripheral artery disease: Current insight into the disease and its diagnosis and management. Mayo Clin. Proc. 2010, 85, 678-692. [CrossRef]

38. Berliner, J.A.; Navab, M.; Fogelman, A.M.; Frank, J.S.; Demer, L.L.; Edwards, P.A.; Watson, A.D.; Lusis, A.J. Atherosclerosis: Basic mechanisms. Oxidation, inflammation, and genetics. Circulation 1995, 91, 2488-2496. [CrossRef] [PubMed]

39. Biomarkers Definitions Working, G. Biomarkers and surrogate endpoints: Preferred definitions and conceptual framework. Clin. Pharmacol. Ther. 2001, 69, 89-95.

40. Finley Austin, M.J.; Babiss, L. Commentary: Where and how could biomarkers be used in 2016? Aaps. J. 2006, 8, E185-E189. [CrossRef]

41. Muszynski, P.; Groblewska, M.; Kulczynska-Przybik, A.; Kulakowska, A.; Mroczko, B. Ykl-40 as a potential biomarker and a possible target in therapeutic strategies of alzheimer's disease. Curr. Neuropharmacol. 2017, 15, 906-917. [CrossRef]

42. Krumholz, H.M. Biomarkers, risk factors, and risk: Clarifying the controversy about surrogate end points and clinical outcomes. Circ. Cardiovasc. Qual. Outcomes 2015, 8, 457-459. [CrossRef] 
43. Vasan, R.S. Biomarkers of cardiovascular disease: Molecular basis and practical considerations. Circulation 2006, 113, 2335-2362. [CrossRef]

44. Wilson, P.W.; D’Agostino, R.B.; Levy, D.; Belanger, A.M.; Silbershatz, H.; Kannel, W.B. Prediction of coronary heart disease using risk factor categories. Circulation 1998, 97, 1837-1847. [CrossRef]

45. Lowe, G.D.; Yarnell, J.W.; Rumley, A.; Bainton, D.; Sweetnam, P.M. C-reactive protein, fibrin d-dimer, and incident ischemic heart disease in the speedwell study: Are inflammation and fibrin turnover linked in pathogenesis? Arter. Thromb. Vasc. Biol. 2001, 21, 603-610. [CrossRef]

46. Chen, S.Y.; Chan, C.C.; Su, T.C. Particulate and gaseous pollutants on inflammation, thrombosis, and autonomic imbalance in subjects at risk for cardiovascular disease. Environ. Pollut. 2017, 223, 403-408. [CrossRef]

47. Omland, T.; White, H.D. State of the art: Blood biomarkers for risk stratification in patients with stable ischemic heart disease. Clin. Chem. 2017, 63, 165-176. [CrossRef]

48. Strandberg, T.E.; Tilvis, R.S. C-reactive protein, cardiovascular risk factors, and mortality in a prospective study in the elderly. Arter. Thromb. Vasc. Biol. 2000, 20, 1057-1060. [CrossRef]

49. Pfutzner, A.; Forst, T. High-sensitivity c-reactive protein as cardiovascular risk marker in patients with diabetes mellitus. Diabetes Technol. Ther. 2006, 8, 28-36. [CrossRef]

50. Apple, F.S.; Collinson, P.O.; Biomarkers, I.T.F.o.C.A.o.C. Analytical characteristics of high-sensitivity cardiac troponin assays. Clin. Chem. 2012, 58, 54-61. [CrossRef] [PubMed]

51. Scirica, B.M.; Morrow, D.A. Troponins in acute coronary syndromes. Prog. Cardiovasc. Dis. 2004, 47, 177-188. [CrossRef]

52. Di Angelantonio, E.; Chowdhury, R.; Sarwar, N.; Ray, K.K.; Gobin, R.; Saleheen, D.; Thompson, A.; Gudnason, V.; Sattar, N.; Danesh, J. B-type natriuretic peptides and cardiovascular risk: Systematic review and meta-analysis of 40 prospective studies. Circulation 2009, 120, 2177-2187. [CrossRef]

53. Tokita, Y.; Kusama, Y.; Kodani, E.; Tadera, T.; Nakagomi, A.; Atarashi, H.; Mizuno, K. Utility of rapid d-dimer measurement for screening of acute cardiovascular disease in the emergency setting. J. Cardiol. 2009, 53, 334-340. [CrossRef] [PubMed]

54. Alehagen, U.; Dahlstrom, U.; Lindahl, T.L. Elevated d-dimer level is an independent risk factor for cardiovascular death in out-patients with symptoms compatible with heart failure. Thromb. Haemost. 2004, 92, 1250-1258. [PubMed]

55. Landry, A.; Docherty, P.; Ouellette, S.; Cartier, L.J. Causes and outcomes of markedly elevated c-reactive protein levels. Can. Fam. Physician Med. Fam. Can. 2017, 63, e316-e323.

56. Zimmermann, O.; Li, K.; Zaczkiewicz, M.; Graf, M.; Liu, Z.; Torzewski, J. C-reactive protein in human atherogenesis: Facts and fiction. Mediat. Inflamm 2014, 2014, 561428. [CrossRef] [PubMed]

57. Chen, Y.; Han, H.; Yan, X.; Ding, F.; Su, X.; Wang, H.; Chen, Q.; Lu, L.; Zhang, R.; Jin, W. Tetranectin as a potential biomarker for stable coronary artery disease. Sci. Rep. 2015, 5, 17632. [CrossRef] [PubMed]

58. Han, Y.; Zhao, S.; Gong, Y.; Hou, G.; Li, X.; Li, L. Serum cyclin-dependent kinase 9 is a potential biomarker of atherosclerotic inflammation. Oncotarget 2016, 7, 1854-1862. [CrossRef] [PubMed]

59. Simonini, M.; Pozzoli, S.; Bignami, E.; Casamassima, N.; Messaggio, E.; Lanzani, C.; Frati, E.; Botticelli, I.M.; Rotatori, F.; Alfieri, O.; et al. Endogenous ouabain: An old cardiotonic steroid as a new biomarker of heart failure and a predictor of mortality after cardiac surgery. Biomed. Res. Int. 2015, 2015, 714793. [CrossRef] [PubMed]

60. Brea, D.; Sobrino, T.; Blanco, M.; Fraga, M.; Agulla, J.; Rodriguez-Yanez, M.; Rodriguez-Gonzalez, R.; Perez de la Ossa, N.; Leira, R.; Forteza, J.; et al. Usefulness of haptoglobin and serum amyloid a proteins as biomarkers for atherothrombotic ischemic stroke diagnosis confirmation. Atherosclerosis 2009, 205, 561-567. [CrossRef] [PubMed]

61. Ceholski, D.K.; Trieber, C.A.; Young, H.S. Hydrophobic imbalance in the cytoplasmic domain of phospholamban is a determinant for lethal dilated cardiomyopathy. J. Biol. Chem. 2012, 287, 16521-16529. [CrossRef]

62. Hochholzer, W.; Morrow, D.A.; Giugliano, R.P. Novel biomarkers in cardiovascular disease: Update 2010. Am. Heart J. 2010, 160, 583-594. [CrossRef]

63. Heslop, C.L.; Frohlich, J.J.; Hill, J.S. Myeloperoxidase and c-reactive protein have combined utility for long-term prediction of cardiovascular mortality after coronary angiography. J. Am. Coll. Cardiol. 2010, 55, 1102-1109. [CrossRef] 
64. Calmarza, P.; Lapresta, C.; Martinez, M.; Lahoz, R.; Povar, J. Utility of Myeloperoxidase in the Differential Diagnosis of Acute Coronary Syndrome; Universidad de Zaragoza Repository: Zaragoza, Spain, 2017.

65. Huang, A.; Huang, Y. Role of sfrps in cardiovascular disease. Ther. Adv. Chronic. Dis. 2020, 11. [CrossRef] [PubMed]

66. Askevold, E.T.; Aukrust, P.; Nymo, S.H.; Lunde, I.G.; Kaasboll, O.J.; Aakhus, S.; Florholmen, G.; Ohm, I.K.; Strand, M.E.; Attramadal, H.; et al. The cardiokine secreted frizzled-related protein 3, a modulator of wnt signalling, in clinical and experimental heart failure. J. Intern. Med. 2014, 275, 621-630. [CrossRef] [PubMed]

67. Meuwese, M.C.; Stroes, E.S.; Hazen, S.L.; van Miert, J.N.; Kuivenhoven, J.A.; Schaub, R.G.; Wareham, N.J.; Luben, R.; Kastelein, J.J.; Khaw, K.T.; et al. Serum myeloperoxidase levels are associated with the future risk of coronary artery disease in apparently healthy individuals: The epic-norfolk prospective population study. J. Am. Coll. Cardiol. 2007, 50, 159-165. [CrossRef]

68. Ndrepepa, G.; Braun, S.; Mehilli, J.; von Beckerath, N.; Schomig, A.; Kastrati, A. Myeloperoxidase level in patients with stable coronary artery disease and acute coronary syndromes. Eur. J. Clin. Investig. 2008, 38, 90-96. [CrossRef]

69. Zhang, R.; Brennan, M.L.; Fu, X.; Aviles, R.J.; Pearce, G.L.; Penn, M.S.; Topol, E.J.; Sprecher, D.L.; Hazen, S.L. Association between myeloperoxidase levels and risk of coronary artery disease. Jama 2001, 286, 2136-2142. [CrossRef]

70. Shridas, P.; Tannock, L.R. Role of serum amyloid a in atherosclerosis. Curr. Opin. Lipidol. 2019, 30, 320-325. [CrossRef]

71. He, Y.; Ma, C.; Xing, J.; Wang, S.; Ji, C.; Han, Y.; Zhang, J. Serum amyloid a protein as a potential biomarker in predicting acute onset and association with in-hospital death in acute aortic dissection. Bmc Cardiovasc. Disord. 2019, 19, 282. [CrossRef]

72. Johnson, B.D.; Kip, K.E.; Marroquin, O.C.; Ridker, P.M.; Kelsey, S.F.; Shaw, L.J.; Pepine, C.J.; Sharaf, B.; Bairey Merz, C.N.; Sopko, G.; et al. Serum amyloid a as a predictor of coronary artery disease and cardiovascular outcome in women: The national heart, lung, and blood institute-sponsored women's ischemia syndrome evaluation (wise). Circulation 2004, 109, 726-732. [CrossRef]

73. Krishack, P.A.; Bhanvadia, C.V.; Lukens, J.; Sontag, T.J.; De Beer, M.C.; Getz, G.S.; Reardon, C.A. Serum amyloid a facilitates early lesion development in ldlr-/- mice. J. Am. Heart Assoc. 2015, 4, e001858. [CrossRef]

74. Wilson, A.M.; Kimura, E.; Harada, R.K.; Nair, N.; Narasimhan, B.; Meng, X.Y.; Zhang, F.; Beck, K.R.; Olin, J.W.; Fung, E.T.; et al. Beta2-microglobulin as a biomarker in peripheral arterial disease: Proteomic profiling and clinical studies. Circulation 2007, 116, 1396-1403. [CrossRef]

75. Curaj, A.; Wu, Z.; Rix, A.; Gresch, O.; Sternkopf, M.; Alampour-Rajabi, S.; Lammers, T.; van Zandvoort, M.; Weber, C.; Koenen, R.R.; et al. Molecular ultrasound imaging of junctional adhesion molecule a depicts acute alterations in blood flow and early endothelial dysregulation. Arter. Thromb. Vasc. Biol. 2018, 38, 40-48. [CrossRef] [PubMed]

76. Soeki, T.; Tamura, Y.; Shinohara, H.; Sakabe, K.; Onose, Y.; Fukuda, N. Increased soluble platelet/endothelial cell adhesion molecule-1 in the early stages of acute coronary syndromes. Int. J. Cardiol. 2003, 90, 261-268. [CrossRef]

77. Ku, E.J.; Cho, K.C.; Lim, C.; Kang, J.W.; Oh, J.W.; Choi, Y.R.; Park, J.M.; Han, N.Y.; Oh, J.J.; Oh, T.J.; et al. Discovery of plasma biomarkers for predicting the severity of coronary artery atherosclerosis by quantitative proteomics. BMJ Open Diabetes Res. Care 2020, 8, e001152. [CrossRef]

78. Soung, Y.H.; Ford, S.; Zhang, V.; Chung, J. Exosomes in cancer diagnostics. Cancers 2017, 9, 8. [CrossRef]

79. Sarko, D.K.; McKinney, C.E. Exosomes: Origins and therapeutic potential for neurodegenerative disease. Front. Neurosci. 2017, 11, 82. [CrossRef]

80. Cheow, E.S.; Cheng, W.C.; Lee, C.N.; de Kleijn, D.; Sorokin, V.; Sze, S.K. Plasma-derived extracellular vesicles contain predictive biomarkers and potential therapeutic targets for myocardial ischemic injury. Mol. Cell. Proteom. Mcp 2016, 15, 2628-2640. [CrossRef]

81. Poe, A.J.; Knowlton, A.A. Exosomes as agents of change in the cardiovascular system. J. Mol. Cell Cardiol. 2017, 111, 40-50. [CrossRef]

82. Valadi, H.; Ekstrom, K.; Bossios, A.; Sjostrand, M.; Lee, J.J.; Lotvall, J.O. Exosome-mediated transfer of mrnas and micrornas is a novel mechanism of genetic exchange between cells. Nat. Cell Biol. 2007, 9, 654-659. [CrossRef] 
83. Cordes, K.R.; Srivastava, D. Microrna regulation of cardiovascular development. Circ. Res. 2009, 104, 724-732. [CrossRef]

84. Hunter, M.P.; Ismail, N.; Zhang, X.; Aguda, B.D.; Lee, E.J.; Yu, L.; Xiao, T.; Schafer, J.; Lee, M.L.; Schmittgen, T.D.; et al. Detection of microrna expression in human peripheral blood microvesicles. PLoS ONE 2008, 3, e3694. [CrossRef]

85. Zernecke, A.; Bidzhekov, K.; Noels, H.; Shagdarsuren, E.; Gan, L.; Denecke, B.; Hristov, M.; Koppel, T.; Jahantigh, M.N.; Lutgens, E.; et al. Delivery of microrna-126 by apoptotic bodies induces cxcl12-dependent vascular protection. Sci. Signal. 2009, 2, ra81. [CrossRef] [PubMed]

86. Arroyo, J.D.; Chevillet, J.R.; Kroh, E.M.; Ruf, I.K.; Pritchard, C.C.; Gibson, D.F.; Mitchell, P.S.; Bennett, C.F.; Pogosova-Agadjanyan, E.L.; Stirewalt, D.L.; et al. Argonaute2 complexes carry a population of circulating micrornas independent of vesicles in human plasma. Proc. Natl. Acad. Sci. USA 2011, 108, 5003-5008. [CrossRef] [PubMed]

87. Vickers, K.C.; Palmisano, B.T.; Shoucri, B.M.; Shamburek, R.D.; Remaley, A.T. Micrornas are transported in plasma and delivered to recipient cells by high-density lipoproteins. Nat. Cell Biol. 2011, 13, 423-433. [CrossRef] [PubMed]

88. Corsten, M.F.; Dennert, R.; Jochems, S.; Kuznetsova, T.; Devaux, Y.; Hofstra, L.; Wagner, D.R.; Staessen, J.A.; Heymans, S.; Schroen, B. Circulating microrna-208b and microrna-499 reflect myocardial damage in cardiovascular disease. Circ. Cardiovasc. Genet. 2010, 3, 499-506. [CrossRef]

89. Huang, Z.; Huang, D.; Ni, S.; Peng, Z.; Sheng, W.; Du, X. Plasma micrornas are promising novel biomarkers for early detection of colorectal cancer. Int. J. Cancer. J. Int. Du Cancer 2010, 127, 118-126. [CrossRef]

90. Khalyfa, A.; Gozal, D. Exosomal mirnas as potential biomarkers of cardiovascular risk in children. J. Transl. Med. 2014, 12, 162. [CrossRef]

91. Ji, X.; Takahashi, R.; Hiura, Y.; Hirokawa, G.; Fukushima, Y.; Iwai, N. Plasma mir-208 as a biomarker of myocardial injury. Clin. Chem. 2009, 55, 1944-1949. [CrossRef]

92. Wang, F.; Yuan, Y.; Yang, P.; Li, X. Extracellular vesicles-mediated transfer of mir-208a/b exaggerate hypoxia/reoxygenation injury in cardiomyocytes by reducing qki expression. Mol. Cell Biochem. 2017, 431, 187-195. [CrossRef]

93. Schroen, B.; Heymans, S. Small but smart-micrornas in the centre of inflammatory processes during cardiovascular diseases, the metabolic syndrome, and ageing. Cardiovasc. Res. 2012, 93, 605-613. [CrossRef]

94. Kuehbacher, A.; Urbich, C.; Zeiher, A.M.; Dimmeler, S. Role of dicer and drosha for endothelial microrna expression and angiogenesis. Circ. Res. 2007, 101, 59-68. [CrossRef]

95. Chen, Y.; Gorski, D.H. Regulation of angiogenesis through a microrna (mir-130a) that down-regulates antiangiogenic homeobox genes gax and hoxa5. Blood 2008, 111, 1217-1226. [CrossRef] [PubMed]

96. Urbich, C.; Kuehbacher, A.; Dimmeler, S. Role of micrornas in vascular diseases, inflammation, and angiogenesis. Cardiovasc. Res. 2008, 79, 581-588. [CrossRef] [PubMed]

97. Sanchez-Gomez, M.C.; Garcia-Mejia, K.A.; Perez-Diaz Conti, M.; Diaz-Rosas, G.; Palma-Lara, I.; Sanchez-Urbina, R.; Klunder-Klunder, M.; Botello-Flores, J.A.; Balderrabano-Saucedo, N.A.; Contreras-Ramos, A. Micrornas association in the cardiac hypertrophy secondary to complex congenital heart disease in children. Pediatric Cardiol. 2017, 38, 991-1003. [CrossRef] [PubMed]

98. Abu-Halima, M.; Meese, E.; Keller, A.; Abdul-Khaliq, H.; Radle-Hurst, T. Analysis of circulating micrornas in patients with repaired tetralogy of fallot with and without heart failure. J. Transl. Med. 2017, 15, 156. [CrossRef] [PubMed]

99. Maciejak, A.; Kiliszek, M.; Opolski, G.; Segiet, A.; Matlak, K.; Dobrzycki, S.; Tulacz, D.; Sygitowicz, G.; Burzynska, B.; Gora, M. Mir-22-5p revealed as a potential biomarker involved in the acute phase of myocardial infarction via profiling of circulating micrornas. Mol. Med. Rep. 2016, 14, 2867-2875. [CrossRef]

100. Njock, M.S.; Fish, J.E. Endothelial mirnas as cellular messengers in cardiometabolic diseases. Trends Endocrinol. Metab. 2017, 28, 237-246. [CrossRef]

101. Rotllan, N.; Price, N.; Pati, P.; Goedeke, L.; Fernandez-Hernando, C. Micrornas in lipoprotein metabolism and cardiometabolic disorders. Atherosclerosis 2016, 246, 352-360. [CrossRef]

102. Li, T.; Cao, H.; Zhuang, J.; Wan, J.; Guan, M.; Yu, B.; Li, X.; Zhang, W. Identification of mir-130a, mir-27b and mir-210 as serum biomarkers for atherosclerosis obliterans. Clin. Chim. Acta 2011, 412, 66-70. [CrossRef] 
103. Han, H.; Qu, G.; Han, C.; Wang, Y.; Sun, T.; Li, F.; Wang, J.; Luo, S. Mir-34a, mir-21 and mir-23a as potential biomarkers for coronary artery disease: A pilot microarray study and confirmation in a 32 patient cohort. Exp. Mol. Med. 2015, 47, e138. [CrossRef]

104. Schlosser, K.; White, R.J.; Stewart, D.J. Mir-26a linked to pulmonary hypertension by global assessment of circulating extracellular micrornas. Am. J. Respir. Crit. Care Med. 2013, 188, 1472-1475. [CrossRef]

105. Derda, A.A.; Thum, S.; Lorenzen, J.M.; Bavendiek, U.; Heineke, J.; Keyser, B.; Stuhrmann, M.; Givens, R.C.; Kennel, P.J.; Schulze, P.C.; et al. Blood-based microrna signatures differentiate various forms of cardiac hypertrophy. Int. J. Cardiol. 2015, 196, 115-122. [CrossRef] [PubMed]

106. Cheng, C.; Wang, Q.; You, W.; Chen, M.; Xia, J. Mirnas as biomarkers of myocardial infarction: A meta-analysis. PLoS ONE 2014, 9, e88566. [CrossRef] [PubMed]

107. Yang, W.; Shao, J.; Bai, X.; Zhang, G. Expression of plasma microrna-1/21/208a/499 in myocardial ischemic reperfusion injury. Cardiology 2015, 130, 237-241. [CrossRef] [PubMed]

108. Chen, Y.; Song, Y.; Huang, J.; Qu, M.; Zhang, Y.; Geng, J.; Zhang, Z.; Liu, J.; Yang, G.Y. Increased circulating exosomal mirna-223 is associated with acute ischemic stroke. Front. Neurol. 2017, 8, 57. [CrossRef] [PubMed]

109. Chu, S.H.; Huang, M.; Kelly, R.S.; Benedetti, E.; Siddiqui, J.K.; Zeleznik, O.A.; Pereira, A.; Herrington, D.; Wheelock, C.E.; Krumsiek, J.; et al. Integration of metabolomic and other omics data in population-based study designs: An epidemiological perspective. Metabolites 2019, 9, 117. [CrossRef]

110. Mbasu, R.J.; Heaney, L.M.; Molloy, B.J.; Hughes, C.J.; Ng, L.L.; Vissers, J.P.; Langridge, J.I.; Jones, D.J. Advances in quadrupole and time-of-flight mass spectrometry for peptide mrm based translational research analysis. Proteomics 2016, 16, 2206-2220. [CrossRef]

111. Bruggeman, F.J.; Westerhoff, H.V. The nature of systems biology. Trends Microbiol. 2007, 15, 45-50. [CrossRef]

112. Kislinger, T.; Emili, A. Going global: Protein expression profiling using shotgun mass spectrometry. Curr. Opin. Mol. Ther. 2003, 5, 285-293.

113. Izquierdo, I.; Rosa, I.; Bravo, S.B.; Guitian, E.; Perez-Serra, A.; Campuzano, O.; Brugada, R.; Mangas, A.; Garcia, A.; Toro, R. Proteomic identification of putative biomarkers for early detection of sudden cardiac death in a family with a lmna gene mutation causing dilated cardiomyopathy. J. Proteom. 2016, 148, 75-84. [CrossRef]

114. Binek, A.; Fernandez-Jimenez, R.; Jorge, I.; Camafeita, E.; Lopez, J.A.; Bagwan, N.; Galan-Arriola, C.; Pun, A.; Aguero, J.; Fuster, V.; et al. Proteomic footprint of myocardial ischemia/reperfusion injury: Longitudinal study of the at-risk and remote regions in the pig model. Sci. Rep. 2017, 7, 12343. [CrossRef]

115. Nagai-Okatani, C.; Minamino, N. Aberrant glycosylation in the left ventricle and plasma of rats with cardiac hypertrophy and heart failure. PLoS ONE 2016, 11, e0150210. [CrossRef] [PubMed]

116. Rossing, K.; Bosselmann, H.S.; Gustafsson, F.; Zhang, Z.Y.; Gu, Y.M.; Kuznetsova, T.; Nkuipou-Kenfack, E.; Mischak, H.; Staessen, J.A.; Koeck, T.; et al. Urinary proteomics pilot study for biomarker discovery and diagnosis in heart failure with reduced ejection fraction. PLoS ONE 2016, 11, e0157167. [CrossRef]

117. Slevin, M.; Elasbali, A.B.; Miguel Turu, M.; Krupinski, J.; Badimon, L.; Gaffney, J. Identification of differential protein expression associated with development of unstable human carotid plaques. Am. J. Pathol. 2006, 168, 1004-1021. [CrossRef]

118. Montezano, A.C.; Touyz, R.M. Molecular mechanisms of hypertension-reactive oxygen species and antioxidants: A basic science update for the clinician. Can. J. Cardiol. 2012, 28, 288-295. [CrossRef] [PubMed]

119. Nagababu, E.; Rifkind, J.M. Measurement of plasma nitrite by chemiluminescence. Methods Mol. Biol. 2010, $610,41-49$.

120. Casey, D.P.; Beck, D.T.; Braith, R.W. Systemic plasma levels of nitrite/nitrate (nox) reflect brachial flow-mediated dilation responses in young men and women. Clin. Exp. Pharm. Physiol. 2007, 34, 1291-1293. [CrossRef]

121. Palm, F.; Onozato, M.L.; Luo, Z.; Wilcox, C.S. Dimethylarginine dimethylaminohydrolase (ddah): Expression, regulation, and function in the cardiovascular and renal systems. Am. J. Physiol. Heart Circ. Physiol. 2007, 293, H3227-H3245. [CrossRef]

122. Xiao, S.; Wagner, L.; Mahaney, J.; Baylis, C. Uremic levels of urea inhibit l-arginine transport in cultured endothelial cells. Am. J. Physiol. Ren. Physiol. 2001, 280, F989-F995. [CrossRef] 
123. Paiva, H.; Kahonen, M.; Lehtimaki, T.; Alfthan, G.; Viikari, J.; Laaksonen, R.; Hutri-Kahonen, N.; Laitinen, T.; Taittonen, L.; Raitakari, O.T.; et al. Levels of asymmetrical dimethylarginine are predictive of brachial artery flow-mediated dilation 6 years later. The cardiovascular risk in young finns study. Atherosclerosis 2010, 212, 512-515. [CrossRef]

124. Juonala, M.; Viikari, J.S.; Alfthan, G.; Marniemi, J.; Kahonen, M.; Taittonen, L.; Laitinen, T.; Raitakari, O.T. Brachial artery flow-mediated dilation and asymmetrical dimethylarginine in the cardiovascular risk in young finns study. Circulation 2007, 116, 1367-1373. [CrossRef]

125. Loeffler, L.F.; Navas-Acien, A.; Brady, T.M.; Miller, E.R., 3rd; Fadrowski, J.J. Uric acid level and elevated blood pressure in us adolescents: National health and nutrition examination survey, 1999-2006. Hypertension 2012, 59, 811-817. [CrossRef]

126. Valkonen, V.P.; Paiva, H.; Salonen, J.T.; Lakka, T.A.; Lehtimaki, T.; Laakso, J.; Laaksonen, R. Risk of acute coronary events and serum concentration of asymmetrical dimethylarginine. Lancet 2001, 358, 2127-2128. [CrossRef]

127. Rassaf, T.; Heiss, C.; Hendgen-Cotta, U.; Balzer, J.; Matern, S.; Kleinbongard, P.; Lee, A.; Lauer, T.; Kelm, M. Plasma nitrite reserve and endothelial function in the human forearm circulation. Free Radic. Biol. Med. 2006, 41, 295-301. [CrossRef]

128. Touyz, R.M.; Briones, A.M. Reactive oxygen species and vascular biology: Implications in human hypertension. Hypertens. Res. Off. J. Jpn. Soc. Hypertens. 2011, 34, 5-14. [CrossRef]

129. Johnson, R.J.; Kang, D.H.; Feig, D.; Kivlighn, S.; Kanellis, J.; Watanabe, S.; Tuttle, K.R.; Rodriguez-Iturbe, B.; Herrera-Acosta, J.; Mazzali, M. Is there a pathogenetic role for uric acid in hypertension and cardiovascular and renal disease? Hypertension 2003, 41, 1183-1190. [CrossRef]

130. Harrison, D.G.; Guzik, T.J.; Lob, H.E.; Madhur, M.S.; Marvar, P.J.; Thabet, S.R.; Vinh, A.; Weyand, C.M. Inflammation, immunity, and hypertension. Hypertension 2011, 57, 132-140. [CrossRef]

131. Sprague, A.H.; Khalil, R.A. Inflammatory cytokines in vascular dysfunction and vascular disease. Biochem. Pharmacol. 2009, 78, 539-552. [CrossRef]

132. Rodrigues, S.F.; de Oliveira, M.A.; dos Santos, R.A.; Soares, A.G.; de Cassia Tostes, R.; Carvalho, M.H.; Fortes, Z.B. Hydralazine reduces leukocyte migration through different mechanisms in spontaneously hypertensive and normotensive rats. Eur. J. Pharm. 2008, 589, 206-214. [CrossRef]

133. De Ciuceis, C.; Amiri, F.; Brassard, P.; Endemann, D.H.; Touyz, R.M.; Schiffrin, E.L. Reduced vascular remodeling, endothelial dysfunction, and oxidative stress in resistance arteries of angiotensin ii-infused macrophage colony-stimulating factor-deficient mice: Evidence for a role in inflammation in angiotensin-induced vascular injury. Arter. Thromb. Vasc. Biol. 2005, 25, 2106-2113. [CrossRef]

134. Preston, R.A.; Ledford, M.; Materson, B.J.; Baltodano, N.M.; Memon, A.; Alonso, A. Effects of severe, uncontrolled hypertension on endothelial activation: Soluble vascular cell adhesion molecule-1, soluble intercellular adhesion molecule-1 and von willebrand factor. J. Hypertens. 2002, 20, 871-877. [CrossRef]

135. Barbaro, N.R.; Fontana, V.; Modolo, R.; De Faria, A.P.; Sabbatini, A.R.; Fonseca, F.H.; Anhe, G.F.; Moreno, H. Increased arterial stiffness in resistant hypertension is associated with inflammatory biomarkers. Blood Press 2015, 24, 7-13. [CrossRef] [PubMed]

136. Bautista, L.E.; Vera, L.M.; Arenas, I.A.; Gamarra, G. Independent association between inflammatory markers (c-reactive protein, interleukin-6, and tnf-alpha) and essential hypertension. J. Hum. Hypertens. 2005, 19, 149-154. [CrossRef] [PubMed]

137. Shalia, K.K.; Mashru, M.R.; Vasvani, J.B.; Mokal, R.A.; Mithbawkar, S.M.; Thakur, P.K. Circulating levels of cell adhesion molecules in hypertension. Indian J. Clin. Biochem. 2009, 24, 388-397. [CrossRef]

138. Oguz, M.M.; Oguz, A.D.; Sanli, C.; Cevik, A. Serum levels of soluble icam-1 in children with pulmonary artery hypertension. Tex. Heart Inst. J. 2014, 41, 159-164. [CrossRef]

139. Kuklinska, A.M.; Mroczko, B.; Musial, W.J.; Usowicz-Szarynska, M.; Sawicki, R.; Borowska, H.; Knapp, M.; Szmitkowski, M. Diagnostic biomarkers of essential arterial hypertension: The value of prostacyclin, nitric oxide, oxidized-ldl, and peroxide measurements. Int. Heart J. 2009, 50, 341-351. [CrossRef]

140. Hage, F.G. C-reactive protein and hypertension. J. Hum. Hypertens. 2014, 28, 410-415. [CrossRef]

141. Mehaffey, E.; Majid, D.S.A. Tumor necrosis factor-alpha, kidney function, and hypertension. Am. J. Physiol. Ren. Physiol. 2017, 313, F1005-F1008. [CrossRef]

142. Yang, P.; Liu, Y.F.; Yang, L.; Wei, Q.; Zeng, H. Mechanism and clinical significance of the prothrombotic state in patients with essential hypertension. Clin. Cardiol. 2010, 33, E81-E86. [CrossRef] 
143. Jan Danser, A.H. Renin and prorenin as biomarkers in hypertension. Curr. Opin. Nephrol. Hypertens. 2012, 21, 508-514. [CrossRef]

144. Asferg, C.; Mogelvang, R.; Flyvbjerg, A.; Frystyk, J.; Jensen, J.S.; Marott, J.L.; Appleyard, M.; Jensen, G.B.; Jeppesen, J. Leptin, not adiponectin, predicts hypertension in the copenhagen city heart study. Am J Hypertens. 2010, 23, 327-333. [CrossRef]

145. Shankar, A.; Xiao, J. Positive relationship between plasma leptin level and hypertension. Hypertension 2010, 56, 623-628. [CrossRef] [PubMed]

146. Kim, D.H.; Kim, C.; Ding, E.L.; Townsend, M.K.; Lipsitz, L.A. Adiponectin levels and the risk of hypertension: A systematic review and meta-analysis. Hypertension 2013, 62, 27-32. [CrossRef] [PubMed]

147. Ghantous, C.M.; Azrak, Z.; Hanache, S.; Abou-Kheir, W.; Zeidan, A. Differential role of leptin and adiponectin in cardiovascular system. Int. J. Endocrinol. 2015, 2015, 534320. [CrossRef] [PubMed]

148. Kaisar, O.M.; Johnson, D.W.; Prins, J.B.; Isbel, N. The role of novel biomarkers of cardiovascular disease in chronic kidney disease: Focus on adiponectin and leptin. Curr. Cardiol. Rev. 2008, 4, 287-292. [CrossRef]

149. Soudani, N.; Ghantous, C.M.; Farhat, Z.; Shebaby, W.N.; Zibara, K.; Zeidan, A. Calcineurin/nfat activation-dependence of leptin synthesis and vascular growth in response to mechanical stretch. Front. Physiol. 2016, 7, 433. [CrossRef]

150. de Haro Moraes, C.; Figueiredo, V.N.; de Faria, A.P.; Barbaro, N.R.; Sabbatini, A.R.; Quinaglia, T.; Ferreira-Melo, S.E.; Martins, L.C.; Demacq, C.; Junior, H.M. High-circulating leptin levels are associated with increased blood pressure in uncontrolled resistant hypertension. J. Hum. Hypertens. 2013, 27, 225-230. [CrossRef]

151. Schafer, K.; Halle, M.; Goeschen, C.; Dellas, C.; Pynn, M.; Loskutoff, D.J.; Konstantinides, S. Leptin promotes vascular remodeling and neointimal growth in mice. Arter. Thromb. Vasc. Biol. 2004, 24, 112-117. [CrossRef]

152. Ebrahimi-Mamaeghani, M.; Mohammadi, S.; Arefhosseini, S.R.; Fallah, P.; Bazi, Z. Adiponectin as a potential biomarker of vascular disease. Vasc. Health Risk Manag. 2015, 11, 55-70.

153. Shibata, R.; Sato, K.; Pimentel, D.R.; Takemura, Y.; Kihara, S.; Ohashi, K.; Funahashi, T.; Ouchi, N.; Walsh, K. Adiponectin protects against myocardial ischemia-reperfusion injury through ampk- and cox-2-dependent mechanisms. Nat. Med. 2005, 11, 1096-1103. [CrossRef] [PubMed]

154. Shibata, R.; Ouchi, N.; Ito, M.; Kihara, S.; Shiojima, I.; Pimentel, D.R.; Kumada, M.; Sato, K.; Schiekofer, S.; Ohashi, K.; et al. Adiponectin-mediated modulation of hypertrophic signals in the heart. Nat. Med. 2004, 10, 1384-1389. [CrossRef]

155. Gonon, A.T.; Widegren, U.; Bulhak, A.; Salehzadeh, F.; Persson, J.; Sjoquist, P.O.; Pernow, J. Adiponectin protects against myocardial ischaemia-reperfusion injury via amp-activated protein kinase, akt, and nitric oxide. Cardiovasc. Res. 2008, 78, 116-122. [CrossRef] [PubMed]

156. Ghantous, C.M.; Farhat, R.; Djouhri, L.; Alashmar, S.; Anlar, G.; Korashy, H.M.; Agouni, A.; Zeidan, A. Molecular mechanisms of adiponectin-induced attenuation of mechanical stretch-mediated vascular remodeling. Oxidative Med. Cell. Longev. 2020, 2020, 6425782. [CrossRef] [PubMed]

Publisher's Note: MDPI stays neutral with regard to jurisdictional claims in published maps and institutional affiliations.

(C) 2020 by the authors. Licensee MDPI, Basel, Switzerland. This article is an open access article distributed under the terms and conditions of the Creative Commons Attribution (CC BY) license (http://creativecommons.org/licenses/by/4.0/). 